\title{
Vertical Characteristics of Raindrops Size Distribution over Sumatra Region from Global Precipitation Measurement Observation
}

\author{
Ravidho Ramadhan ${ }^{1}$, Marzuki ${ }^{1 *}$, Harmadi ${ }^{1}$ \\ ${ }^{1}$ Department of Physics, Universitas Andalas, Padang 25163, Indonesia
}

\begin{abstract}
The climatology of the vertical profile of raindrops size distribution (DSD) over Sumatra Region $\left(10^{\circ} \mathrm{S}-10^{\circ} \mathrm{N}, 90^{\circ} \mathrm{E}-110^{\circ} \mathrm{E}\right)$ has been investigated using Global Precipitation Measurement (GPM) level 2 data from January 2015 to June 2018. DSD's vertical profile was observed through a vertical profile of corrected radar reflectivity $\left(Z_{\mathrm{e}}\right)$ and two parameters of normalized gamma DSD, i.e., mass-weight mean diameter $\left(D_{\mathrm{m}}\right)$ and total drops concentration $\left(N_{\mathrm{w}}\right)$. Land-ocean contrast and rain type dependence of DSD over Sumatra were clearly observed. The values of $D_{\mathrm{m}}$ and $N_{\mathrm{w}}$ were larger in the land than in the ocean. Negative and positive gradients of $D_{\mathrm{m}}$ toward the surface were dominant during stratiform and convective rains, respectively, consistent with the $Z$ gradient. Moreover, the negative gradient of stratiform rain in the ocean is larger than in land. Thus, the depletion of large drops is dominant over the ocean, which is due to the break-up process that can be observed from the increase of $N_{w}$. Raindrop growth of convective rains is more robust over the ocean than land that can be seen from a larger value of $D_{\mathrm{m}}$ gradient. The BB strength is slightly larger over land and coastal region than over the ocean, indicating that the riming process is more dominant over land and coastal regions than the ocean.
\end{abstract}

\section{Keywords:}

Raindrop Size Distribution (DSD); GPM; Sumatra;

Stratiform;

Convective.

Article History:

Received: $06 \quad$ February 2021

Revised: 28 April 2021

Accepted: 08 May 2021

Published: $\quad 01 \quad$ June 2021

\section{1- Introduction}

Raindrops size distribution (DSD) is essential to understand the physical process of rainfall events [1]. It can reflect the processes experienced by the raindrop as they fall to the ground. By knowing the vertical profile of DSD, we can understand the microphysical process of drop evolution [2-4]. Moreover, knowledge of DSD is also used to estimate rain attenuation in telecommunication technology using microwave [5-7] and design space-based precipitation radar system $[8,9]$.

The vertical profile of DSD varies in space and time that can influence the application of DSD. For example, constant DSD is commonly used to derive the $Z-R$ relationship for weather radar data conversion. This would be less accurate to estimate rainfall because of the variation of the vertical structure of DSD [10-12]. There are some DSD variability such as regional variability $[13,14]$, rainfall type $[15,16]$, diurnal variability $[6,17,18]$, seasonal variability $[19-20]$, and intraseasonal variability [21].

Surface-based radar is the most common instrument to observe DSD's vertical profile, but it has some limitations, particularly regarding observation coverage. To overcome the limitation of surface radar, satellite-based radar or spaceborne radar can be another option that can cover broader observational areas. Before 2014, we do not have any satellite-based radar capable of observing DSD until Global Precipitation Measurement (GPM) was launched in

* CONTACT: Marzuki@sci.unand.ac.id

DOI: http://dx.doi.org/10.28991/esj-2021-01274

(C) 2021 by the authors. Licensee ESJ, Italy. This is an open access article under the terms and conditions of the Creative Commons Attribution (CC-BY) license (https://creativecommons.org/licenses/by/4.0/). 
February 2014 [22]. The GPM is an advanced Tropical Rainfall Measuring Mission (TRMM) project that provides some precipitation parameters, including DSD parameters.

This work uses GPM data to investigate the vertical characteristics of DSD over Sumatra region. Sumatra is located in the tropical region's warm pool, which is the most active convective area in the world [23]. Several studies have been conducted to study the vertical profile of DSD over Sumatra [18, 24, 25]. Renggono et al. [24] observed DSD's vertical profile using Equatorial Atmospheric Radar (EAR). Marzuki et al. [25] and Ramadhan et al. [18, 20] observed the vertical profile of DSD using Micro Rain Radar (MRR). Using this instrument, they found the rainfall type and diurnal variation of DSD in Sumatra. However, all previous studies were only conducted at one location, namely, at the Equatorial Atmosphere Observation, which is located in Kototabang, West Sumatra $\left(0.20^{\circ} \mathrm{S}, 100.32^{\circ} \mathrm{E} ; 865 \mathrm{~m}\right.$ above sea level). Therefore, to describe DSD's vertical characteristics over the whole Sumatra Region, we used the data of GPM level 2. The GPM data provide two parameters of normalized gamma DSD, i.e., mass-weight mean diameter $\left(D_{\mathrm{m}}\right)$ and total drops concentration $\left(N_{\mathrm{w}}\right)$. The performance of GPM to estimate the DSD parameters has been examined by several studies [26-28].

\section{2- Data and Methodology}

The region of interest is Sumatra and the surrounding ocean $\left(10^{\circ} \mathrm{S}-10^{\circ} \mathrm{N}, 90^{\circ} \mathrm{E}-110^{\circ} \mathrm{E}\right)$. The GPM level 2 data of the study area from January 2015 to June 2018 are used. GPM carries Dual-Frequency Precipitation Radar (DPR) that was Ku-band $(13.6 \mathrm{GHz})$ and Ka-band $(35.5 \mathrm{GHz})$ frequency radar [22, 29]. The type of DPR scanning proceeds three modes of data, i.e., Normal Scan (NS), Match Scan (MS), and High-sensitivity Scan (HS). This mode is produced from different scanning in which NS is from Ku-band scanning while MS and HS are from Ku and Ka combinations. Although NS was produced only from Ku-band scanning, previous studies show good performance of NS scanning for DSD observation in comparison with a ground radar $[28,30]$. Ku band has $125 \mathrm{~m}$ vertical resolution with 176 range bin and 49 swath with $5 \times 5 \mathrm{~km}$ resolution approximately.

The GPM DPR level 2 data are classified into convective and stratiform rains using the classification method, which is available in the classification (CSF) module of GPM [31]. The GPM algorithms consist of the preparation (PRE) module, the vertical (VER) profile module, the classification (CSF) module, the drops size distribution (DSD) module, the surface reference technique (SRT) module, and the solver (SLV) module [32]. This paper used GPM level 2 data version 5 (V05) that was released in May 2017. This version included precipitation at the surface and additional parameters like some parameters and flag, freezing level altitude, and land surface type [33]. The CSF modules used in this study were type precipitation, quality $\mathrm{BB}$, quality rain type precipitation, height $\mathrm{BB}$, bin of $\mathrm{BB}$ top, and bin of $\mathrm{BB}$ bottom. We only analyze the data if quality $\mathrm{BB}$ and quality rain type precipitation are 1 . Finally, we also used the precipitation near surface, $Z$ factor corrected $\left(Z_{\mathrm{e}}\right)$, and DSD parameter data, which are obtained from the SLV module.

GPM provides mass-weight mean diameter $\left(D_{\mathrm{m}}\right)$ in mm and total drops concentration $\left(N_{\mathrm{w}}\right)$ in $\mathrm{dB} N_{\mathrm{w}}$ unit. These parameters are belong to normalized gamma distribution [34] expressed by:

$$
N(D)=N_{w} f(\mu)\left(\frac{D}{D_{m}}\right)^{\mu} \exp \left[-(4+\mu) \frac{D}{D_{m}}\right]
$$

where $D$ is drops diameter in $\mathrm{mm}, N(D)$ is the number of density in $\mathrm{m}^{-3} \mathrm{~mm}^{-1}$, and $f(\mu)$ is a function of shape parameter $(\mu)$ :

$$
f(\mu)=\frac{6}{256} \frac{(4+\mu)^{\mu}}{\Gamma(\mu+4)}
$$

Parameter $N_{w}$ in $\mathrm{mm}^{-3}$ is the ratio between liquid water content $(W)$ in $\mathrm{gm}^{-3}$ and parameter $D_{\mathrm{m}}$ [35], while $D_{\mathrm{m}}$ is the ratio for the fourth to third moment from DSD. The parameter $N_{\mathrm{w}}$ is expressed by:

$$
N_{w}=\frac{256}{\pi \rho_{w}} \frac{10^{3} \mathrm{~W}}{D_{m}^{4}}
$$

where $\rho_{w}$ is the density of water in $\mathrm{gm}^{-3}$. This study does not retrieve the DSD parameters manually, we use $D_{\mathrm{m}}$ and $N_{\mathrm{w}}$ that the GPM has been provided. These parameters were calculated from the rainfall rate $(R)-D_{\mathrm{m}}$ relationship that tends to $Z_{\mathrm{e}}$ observation [36]. Details theoretical basis of this algorithm can be seen in Iguchi et al. [37]. 

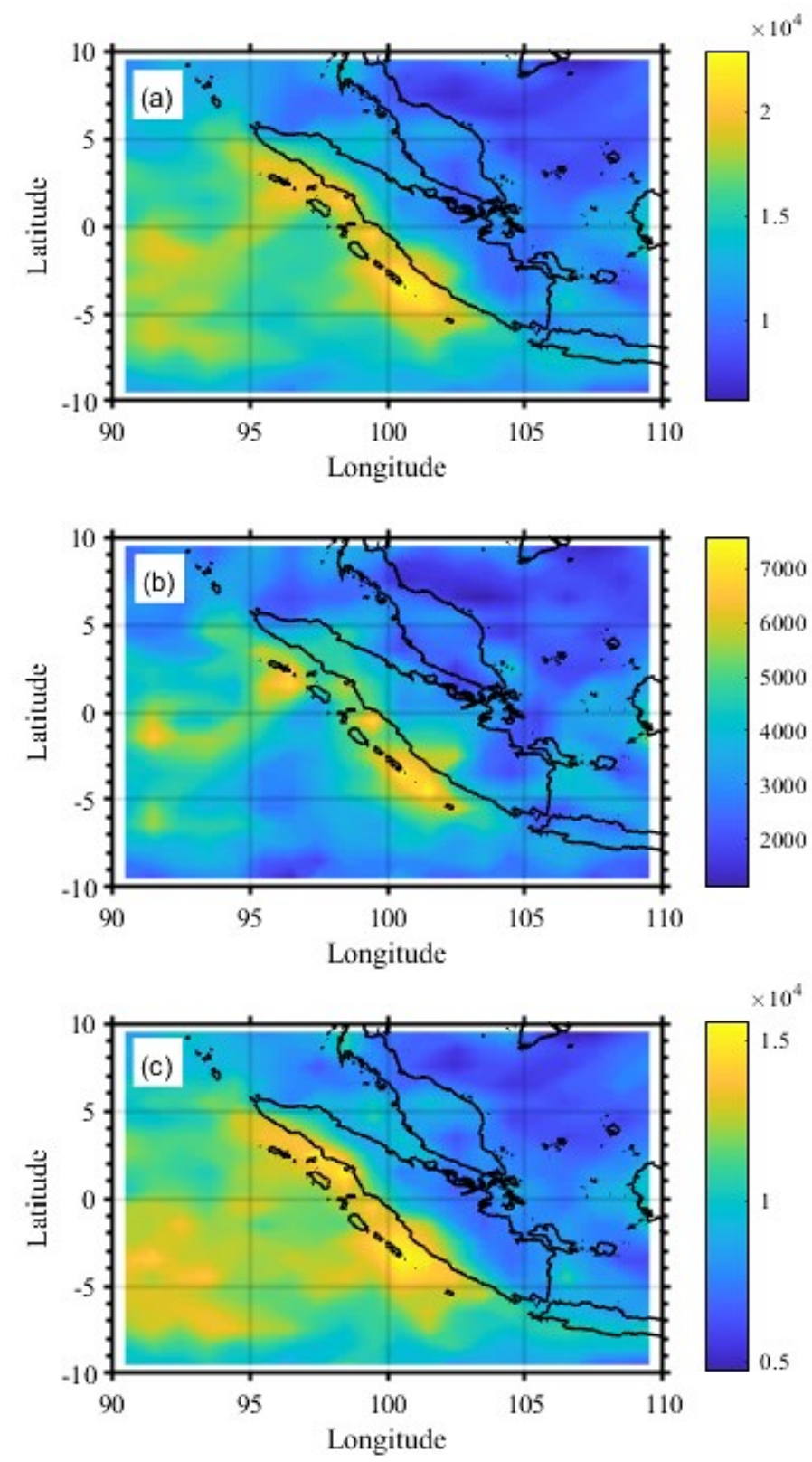

Figure 1. Spatial distribution of GPM level 2 data for a) all rainfall types, b) stratiform rain, and c) convective rain.

This study investigated the vertical structure of DSD over the Sumatra region by filtering the data for near-surface rainfall greater than $0.1 \mathrm{~mm} / \mathrm{h}$. We used the precipitation classification from the GPM level 2 data to divide rainfall types into stratiform and convective rain. The spatial distribution of data was given in Figure 1. It contained 5,325,630 data for all rainfall event (Figure 1a), 1,389,261 data for stratiform rain (Figure 1b), and 3,936,369 data for convective rain (Figure 1c). Usually, the number of stratiform rain profiles is the largest [18, 20], but we found the stratiform rain profile is smaller than convective rain in this study. We compared both stratiform and convective DSD characteristics for several locations, including land, coastal, strait, and ocean, to find the variability.

\section{3- Results}

Figure 2 shows the spatial distribution of the vertical profile of reflectivity gradient (VPRG) above and below the melting layer. It can be used to identify the growth of hydrometeors. Above the melting layer, the gradient was calculated in 5-7 km rain column, while below the melting layer, the VPRG was calculated at the altitude of 1-3 km. All gradients above the melting layer are positive (downward increasing toward the surface, hereafter DI) both for both stratiform and convective rain (Figures $2 \mathrm{a}$ and $2 \mathrm{c}$ ).

Stratiform rain has larger DI above melting layer than convective rain, consistent with characteristics of the convective-stratiform formation. Although DI above the melting layer is positive for convective and stratiform, below the melting layer, stratiform has negative VPRG, while convective rain has positive values. 

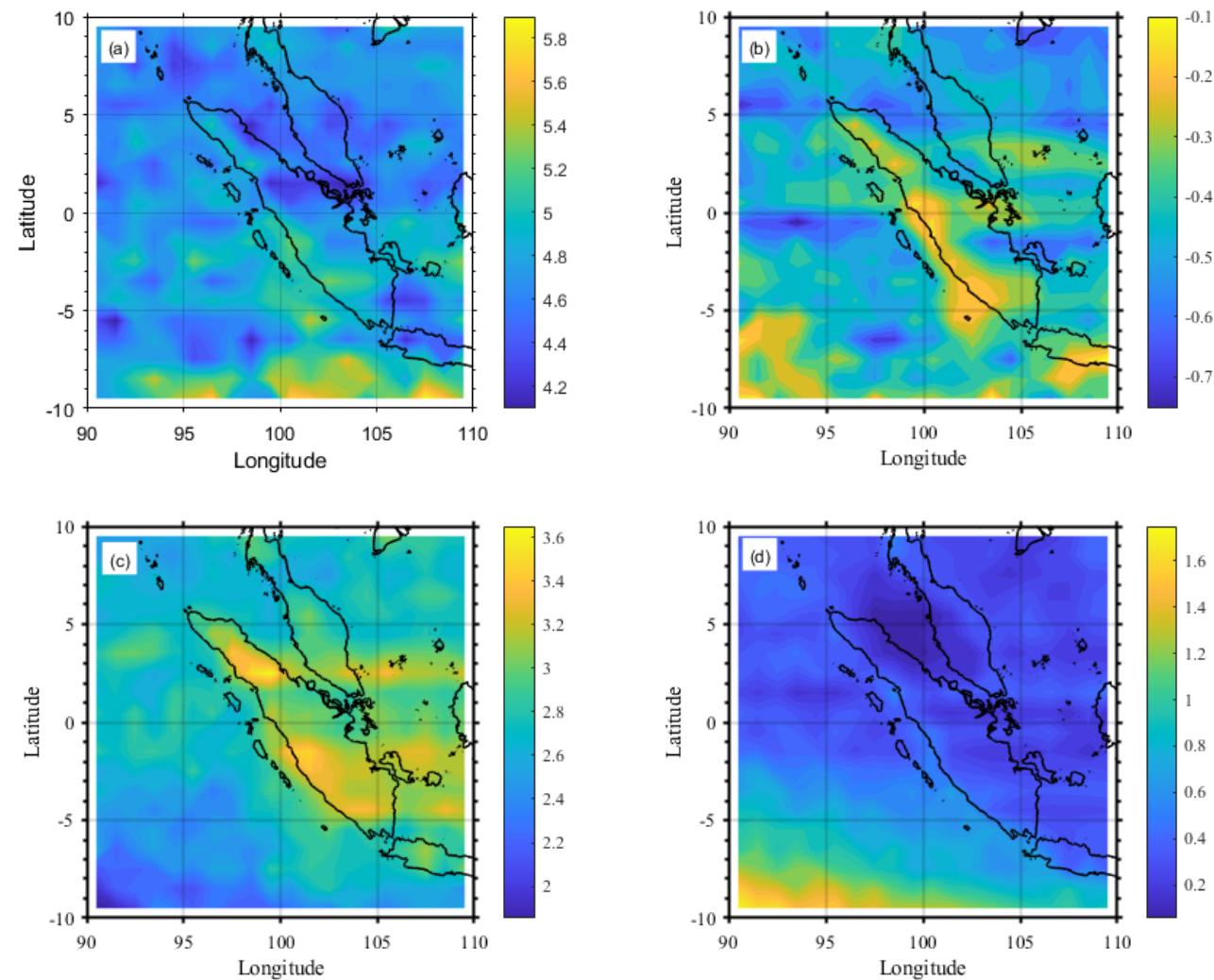

Figure 2. Spatial distribution of vertical profile of reflectivity gradient (VPRG) for stratiform rain at the altitude of 5 - $7 \mathrm{~km}$ (a), and 1 - $3 \mathrm{~km} \mathrm{(b),} \mathrm{and} \mathrm{convective} \mathrm{rain} \mathrm{at} \mathrm{the} \mathrm{altitude} \mathrm{of} 5$ - $7 \mathrm{~km}$ (c), and $1-3 \mathrm{~km}$ (d).
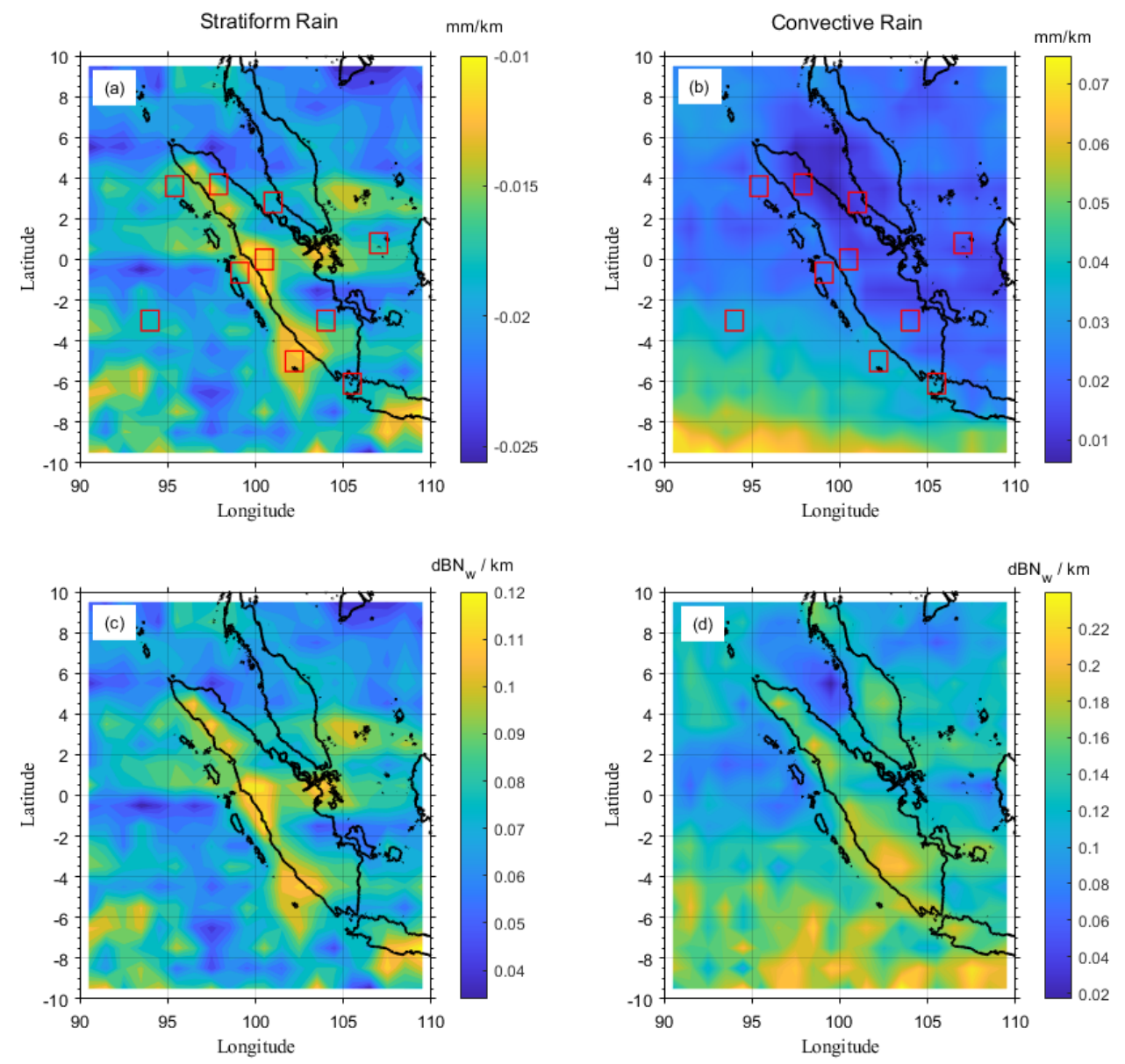

Figure 3. Spatial distribution of vertical gradient of $D_{\mathrm{m}}$ for stratiform (a) and convective (b) rains, and for $N_{\mathrm{w}}$ (c and d). The gradient was calculated at the altitude of $1.5-4 \mathrm{~km}$. 
VPRG for stratiform and convective rains show a regional variation. Above the melting layer, the stratiform's DI gradient is larger over the ocean than over land (Figure 2a). A slightly larger DI gradient of stratiform rain over the land was observed on Sumatra's western coast, which is consistent with the previous study in Indonesia Maritime Continent (IMC) $[38,39]$. Otherwise, the DI gradient of convective rain is larger over the land than over the ocean, especially in the western region of Sumatra (Figure 2c). Thus, the growth of hydrometeor for convective rain is more robust over land, while for stratiform rain, it is more dominant over the ocean [40]. A larger positive DI gradient (positive VPRG) is observed below the melting layer during convective rain over the ocean, indicating that the increase of large-size drops concentration is more significant over the ocean. On the other hand, stratiform rain shows a larger negative gradient of VPRG over this region (Figure 2b), indicating the decrease of large-size drops concentration, consistent with the $D_{\mathrm{m}}$ gradient for the below-melting layer (Figure 3).
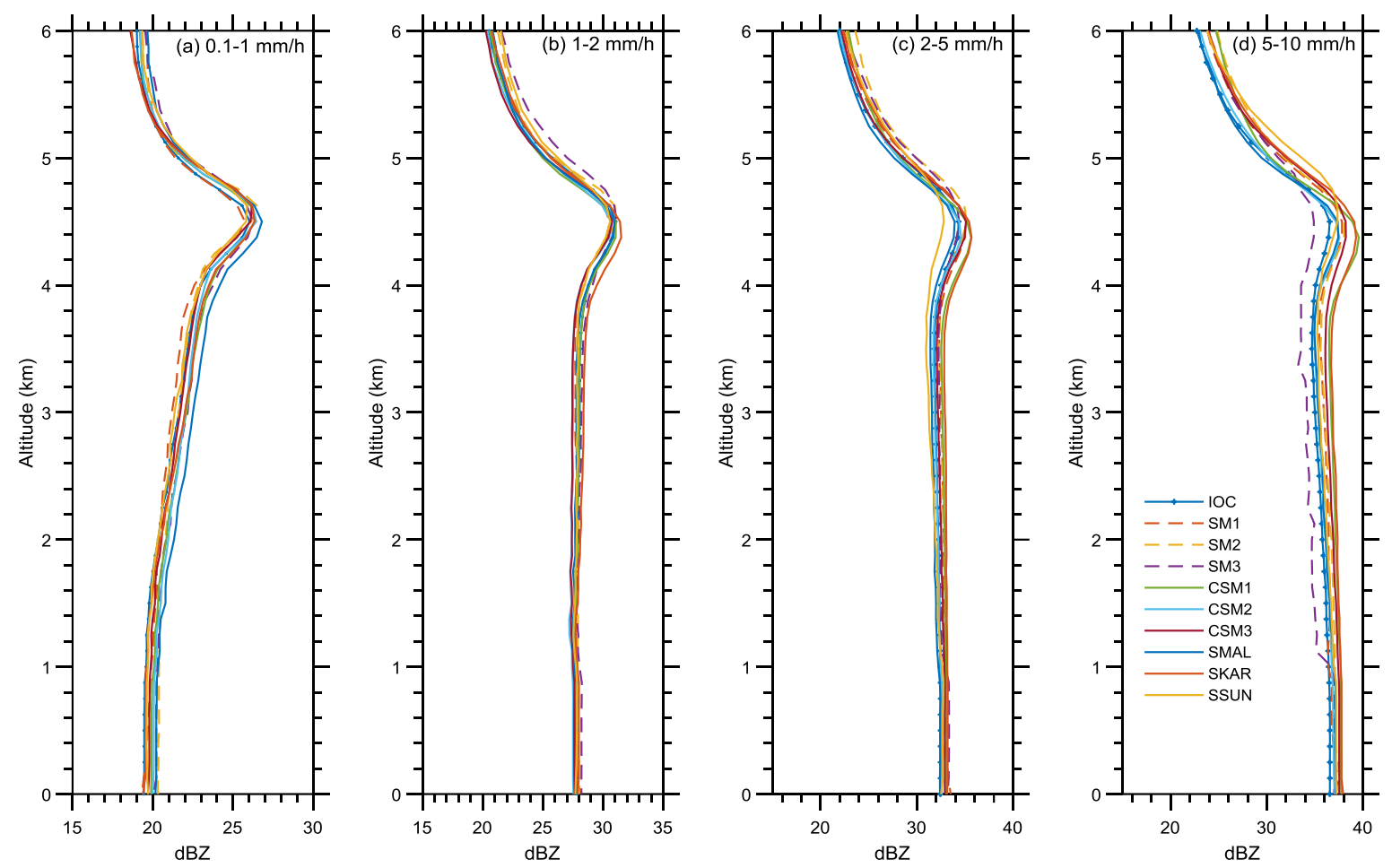

Figure 4. Vertical profile of reflectivity factor $(Z)$ for ten selected locations of stratiform rain for a) very light rain, b) light rain, c) moderate rain, and d) heavy rain.

Gradients of $D_{\mathrm{m}}$ and $N_{\mathrm{w}}$ for stratiform and convective are given in Figure 3. The gradients were calculated in the rain column 1.5-4.0 km. A negative gradient was observed for the vertical profile of $D_{\mathrm{m}}$ during stratiform rain (Figure 3a). It means there is a decrease of large-sized drops toward the surface during stratiform rain over Sumatra region, which is consistent with the VPRG trend (Figure 2b). The decreasing $D_{\mathrm{m}}$ trend for stratiform rain is followed by $N_{\mathrm{w}}$ 's increase that indicates the break-up process [42]. This result is different from previous studies at Kototabang in west Sumatra using MRR [18, 20, 42]. It may be due to a small-scale variability of vertical DSD over Sumatra. Therefore, we analyze the DSD for ten selected locations include Kototabang in Section 3.1.

Table 1. Distribution of data for several locations of stratiform rain from GPM observation.

\begin{tabular}{|c|c|c|c|c|c|c|c|c|}
\hline \multirow{2}{*}{ No. } & \multirow{2}{*}{ Name } & \multirow{2}{*}{ Location } & \multicolumn{6}{|c|}{ Total Data } \\
\hline & & & $0.1 \leq R<1$ & $1 \leq R<2$ & $2 \leq R<5$ & $5 \leq R<10$ & $10 \leq R<20$ & $\grave{R} \geq 20$ \\
\hline 1 & Indian Ocean (IOC) & $2.5^{\circ}-3.5^{\circ} \mathrm{S}, 93.5^{\circ}-94.5^{\circ} \mathrm{E}$ & 2170 & 946 & 1046 & 292 & 2170 & 946 \\
\hline 2 & Sumatra 1 (SM1) & $3.19^{\circ}-4.19^{\circ} \mathrm{N}, 97.4^{\circ}-98.4^{\circ} \mathrm{E}$ & 2368 & 1123 & 1156 & 252 & 2368 & 1123 \\
\hline 3 & Sumatra 2 (SM2) & $0.5^{\circ} \mathrm{S}-0.5^{\circ} \mathrm{N}, 100^{\circ}-101^{\circ} \mathrm{E}$ & 1872 & 777 & 685 & 162 & 1872 & 777 \\
\hline 4 & Sumatra 3 (SM3) & $3.5^{\circ}-2.5^{\circ} \mathrm{S}, 103.5^{\circ}-104.5^{\circ} \mathrm{E}$ & 937 & 398 & 300 & 26 & 937 & 398 \\
\hline 5 & Coastal Sumatra 1 (CSM 1) & $3.1^{\circ}-4.1^{\circ} \mathrm{N}, 94.9^{\circ}-95.9^{\circ} \mathrm{E}$ & 2556 & 1182 & 1432 & 654 & 2556 & 1182 \\
\hline 6 & Coastal Sumatra 2 (CSM 2) & $1.15^{\circ}-0.15^{\circ} \mathrm{S}, 98.6^{\circ}-99.6^{\circ} \mathrm{E}$ & 2813 & 1338 & 1513 & 450 & 2813 & 1338 \\
\hline 7 & Coastal Sumatra 3 (CSM 3) & $5.5^{\circ}-4.5^{\circ} \mathrm{S}, 101.7^{\circ}-102.7^{\circ} \mathrm{E}$ & 2735 & 1399 & 1858 & 827 & 2735 & 1399 \\
\hline 8 & Strait of Malacca (SMAL) & $2.3^{\circ}-3.3^{\circ} \mathrm{N}, 100.5^{\circ}-101.5^{\circ} \mathrm{E}$ & 1470 & 754 & 640 & 217 & 1470 & 754 \\
\hline 9 & Strait of Karimata (SKAR) & $0.3^{\circ}-1.3^{\circ} \mathrm{N}, 106.5^{\circ}-107.5^{\circ} \mathrm{E}$ & 1822 & 788 & 845 & 201 & 1822 & 788 \\
\hline 10 & Strait of Sunda (SSUN) & $6.6^{\circ}-5.6^{\circ} \mathrm{S}, 105^{\circ}-106^{\circ} \mathrm{E}$ & 829 & 323 & 342 & 137 & 829 & 323 \\
\hline
\end{tabular}


Figure $3 \mathrm{~b}$ and d show the spatial distribution of $D_{\mathrm{m}}$ and $N_{\mathrm{w}}$ gradients for convective rain. It can be seen that convective rain has a positive gradient for both $D_{\mathrm{m}}$ and $N_{\mathrm{w}}$ parameters, consistent with the VPRG pattern (Figure 2d). The $D_{\mathrm{m}}$ gradient is smaller over the land than over the ocean. This confirms a smaller increase of large drop concentration over land, as indicated by a small VPRG gradient (Figure 2d). The increase of $D_{\mathrm{m}}$ for convective rain coincides with an increase of gradient $N_{\mathrm{w}}$. The increase of large-sized drops with the increasing total number of raindrops is likely due to several microphysical processes such as the accretion break-up and coalescence [41]. Break-up and coalescence processes occur during the convective rain over the ocean and land. However, the break-up processes are more dominant, especially over the ocean, indicated by a more significant increase of $N_{\mathrm{w}}$.

\section{3-1-Vertical Characteristics of Stratiform Rain}

Figure 4 shows the vertical profile of the corrected radar reflectivity factor $\left(Z_{\mathrm{e}}\right)$ during stratiform rains from GPM observation for several locations over Sumatra. The selected area locations are given in Figures $3 \mathrm{a}$ and $3 \mathrm{~b}$, and the data distribution for these regions was presented in Table 1 . The bright band (BB) appears for all rainfall intensities $(R)$. To identify rainfall intensity dependence of vertical structure of stratiform precipitation, the data are classified into several classes of intensity i.e., very light rain $(0.1 \leq R<1)$, light rain $(1 \leq R<2)$, moderate rain $(2 \leq R<5)$, and heavy rain $(5 \leq R<10)$ [2]. We calculated the BB strength $(\Delta Z)$ by taking the difference in the average value of $Z_{\mathrm{e}}$ between Bright Band Height $(\mathrm{BBH})$ and $\mathrm{BB}$-bottom. The strength of $\mathrm{BB}$ is necessary to identify the number and size of the raindrop during their formation [43].
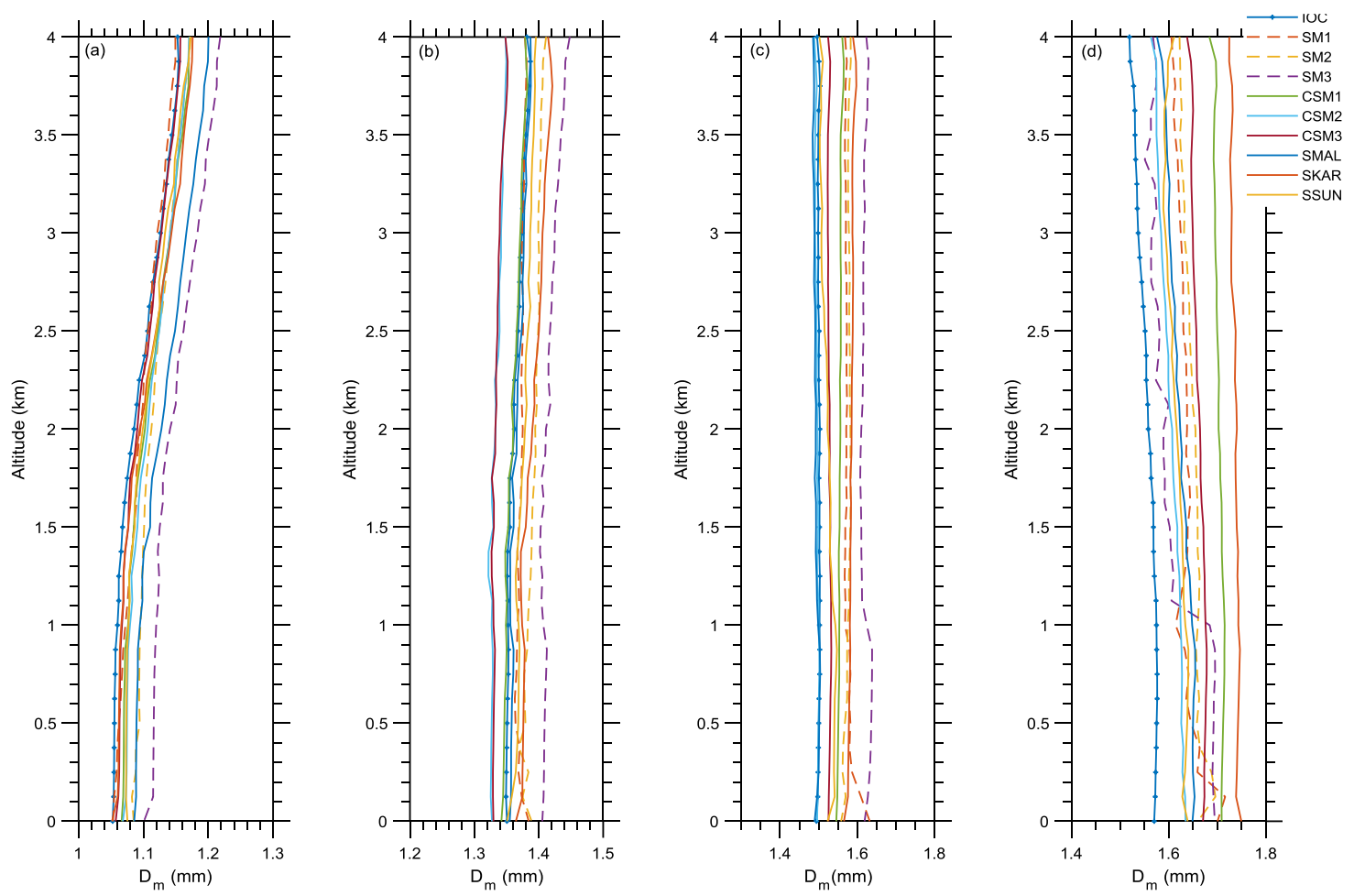

Figure 5. Vertical profile of mass-weight mean diameter $\left(D_{m}\right)$ for ten selected locations of stratiform rain for a) very light rain, b) light rain, c) moderate rain, and d) heavy rain.

The BB strength $(\Delta Z)$ for each location is slightly different. The values of $\Delta Z$ (in $\mathrm{dBZ}$ ) for very light rain are IOC (4.28), SM1 (4.50), SM2 (4.48), SM3 (4.15), CSM1 (4.04), CSM2 (4.27), CSM3 (4.14), SMAL (4.21), SKAR (4.09), and SSUN (4.12). Furthermore, $\Delta Z$ for heavy rain are IOC (2.62), SM1 (2.79), SM2 (2.89), SM3 (2.24), CSM1 (3.24), CSM2 (2.80), CSM3 (2.95), SMAL (3.06), SKAR (2.63), SSUN (2.41). Thus, very light rain has a larger $\Delta Z$ than heavy rain, which indicates a more dominant break up or riming process [44]. The strength of $\Delta Z$ is closely related to the decrease of large-sized drop soon after the ice crystal melts. There is a significant rain intensity dependence of VPRG below the melting layer. Very light rain has a negative gradient, while heavy rain has a positive gradient (Figure 4). This feature indicates the decrease of large-sized drops concentration during very light rain over Sumatra. The values of $\Delta Z$ during heavy rain for several coastal areas such as CSM1, CSM2, and CSM3 are larger than in other regions.

Figure 5 shows the vertical profile of $D_{\mathrm{m}}$ for all classes of stratiform rain. The values of $D_{\mathrm{m}}$ increase with an increasing rainfall rate. This is typical of DSD characteristics in the tropics $[2,14]$. The value of $D_{\mathrm{m}}$ over land (SM1, SM2, SM3) is larger than other regions, indicating a smaller growth of raindrops over land than ocean, coastal, and strait, as observed in Figure 2. For very light to moderate rain, the larger value $D_{\mathrm{m}}$ was observed over land (SM2 and SM3). The larger $D_{\mathrm{m}}$ over land is associated with a smaller value of $N_{\mathrm{w}}$ (Figure 6). A similar pattern is also observed in the coastal region (CSM3). Thus, the DSD of stratiform rain over land comprises more large-sized drop concentrations with a small number of raindrop total. This fact is consistent with weak BB over land (Figure 4). 

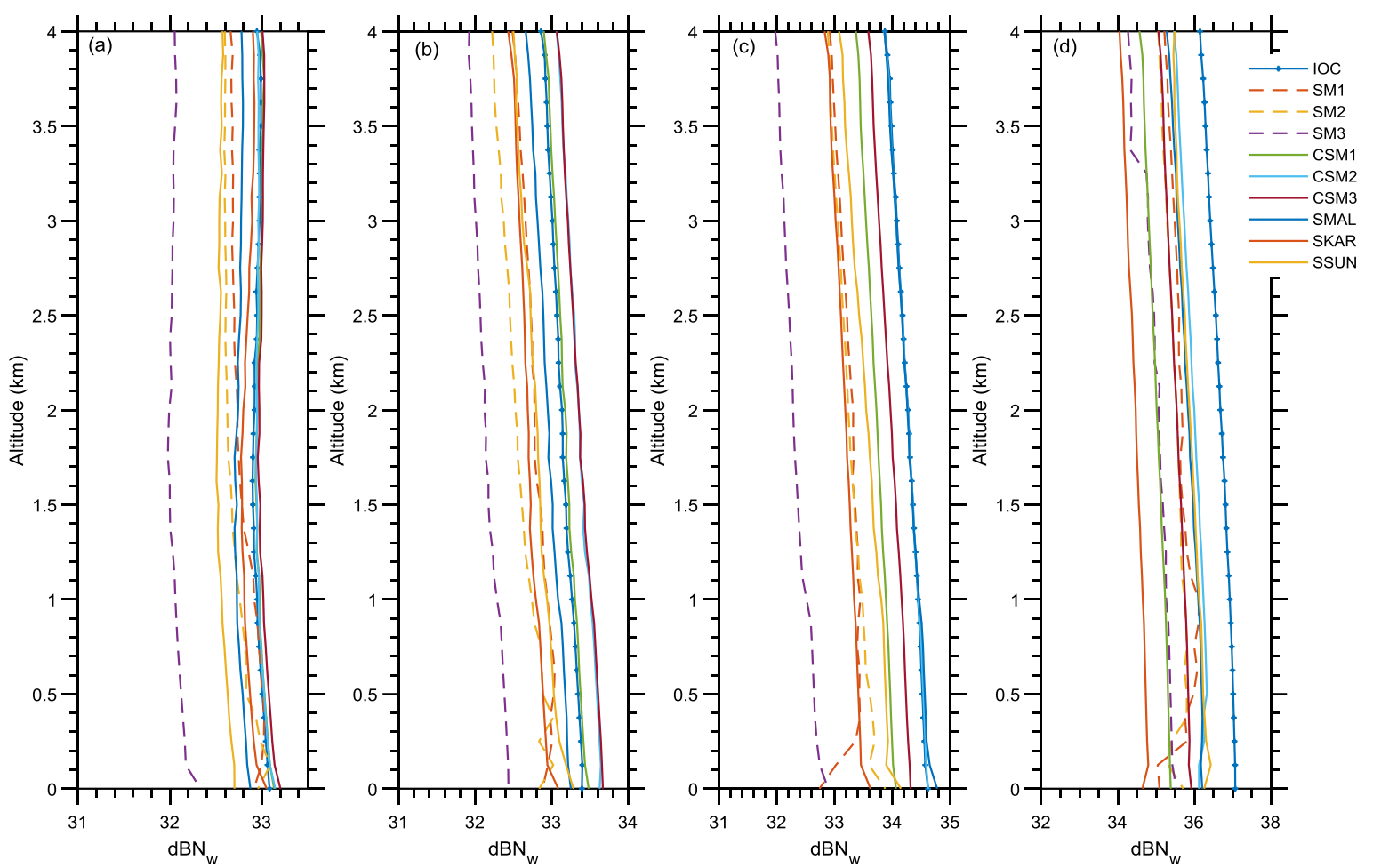

Figure 6. Vertical profile of total drop concentration $\left(\mathrm{dB} N_{\mathrm{w}}\right)$ for ten selected locations of stratiform rain for a) very light rain, b) light rain, c) moderate rain, and d) heavy rain.

\section{3-2-Vertical Characteristics of Convective Rain}

Figure 7 shows $Z_{\mathrm{e}}$ 's vertical profile during convective rains for several locations, which are indicated in Figures 3a and $3 \mathrm{~b}$. The data distribution for these regions was presented in Table 2 . We classified convective rain into six rain intensities i.e. very light rain $(0.1 \leq R<1)$, light rain $(1 \leq R<2)$, moderate rain $(2 \leq R<5)$, heavy rain $(5 \leq R<10)$, very heavy rain $(10 \leq R<20)$, and extreme rain $(R \geq 20)[2]$.

Table 2. Distribution of data for several locations of convective rain from GPM observation.

\begin{tabular}{|c|c|c|c|c|c|c|c|c|}
\hline \multirow{2}{*}{ No. } & \multirow{2}{*}{ Name } & \multirow{2}{*}{ Location } & \multicolumn{6}{|c|}{ Total Data } \\
\hline & & & $0.1 \leq R<1$ & $1 \leq R<2$ & $2 \leq R<5$ & $5 \leq R<10$ & $10 \leq R<20$ & $\grave{R} \geq 20$ \\
\hline 1 & Indian Ocean (IOC) & $2.5^{\circ}-3.5^{\circ} \mathrm{S}, 93.5^{\circ}-94.5^{\circ} \mathrm{E}$ & 7298 & 2083 & 1940 & 655 & 390 & 481 \\
\hline 2 & Sumatra 1 (SM1) & $3.19^{\circ}-4.19^{\circ} \mathrm{N}, 97.4^{\circ}-98.4^{\circ} \mathrm{E}$ & 6486 & 2079 & 1931 & 709 & 284 & 246 \\
\hline 3 & Sumatra 2 (SM2) & $0.5^{\circ} \mathrm{S}-0.5^{\circ} \mathrm{N}, 100^{\circ}-101^{\circ} \mathrm{E}$ & 5112 & 1796 & 1588 & 544 & 263 & 144 \\
\hline 4 & Sumatra 3 (SM3) & $3.5^{\circ}-2.5^{\circ} \mathrm{S}, 103.5^{\circ}-104.5^{\circ} \mathrm{E}$ & 4089 & 1320 & 1082 & 346 & 140 & 107 \\
\hline 5 & Coastal Sumatra 1 (CSM 1) & $3.1^{\circ}-4.1^{\circ} \mathrm{N}, 94.9^{\circ}-95.9^{\circ} \mathrm{E}$ & 8070 & 2103 & 2042 & - & 402 & 437 \\
\hline 6 & Coastal Sumatra 2 (CSM 2) & $1.15^{\circ}-0.15^{\circ} \mathrm{S}, 98.6^{\circ}-99.6^{\circ} \mathrm{E}$ & 8137 & 2280 & 2228 & 842 & 412 & 456 \\
\hline 7 & Coastal Sumatra 3 (CSM 3) & $5.5^{\circ}-4.5^{\circ} \mathrm{S}, 101.7^{\circ}-102.7^{\circ} \mathrm{E}$ & 7360 & 2186 & 2326 & 1068 & 572 & 570 \\
\hline 8 & Strait of Malacca (SMAL) & $2.3^{\circ}-3.3^{\circ} \mathrm{N}, 100.5^{\circ}-101.5^{\circ} \mathrm{E}$ & 5928 & 1693 & 1659 & 680 & 374 & 426 \\
\hline 9 & Strait of Karimata (SKAR) & $0.3^{\circ}-1.3^{\circ} \mathrm{N}, 106.5^{\circ}-107.5^{\circ} \mathrm{E}$ & 4815 & 1087 & 1050 & 432 & 193 & 179 \\
\hline 10 & Strait of Sunda (SSUN) & $6.6^{\circ}-5.6^{\circ} \mathrm{S}, 105^{\circ}-106^{\circ} \mathrm{E}$ & 4992 & 1516 & 1387 & 586 & 285 & 256 \\
\hline
\end{tabular}

High rainfall intensity is associated with a larger positive VPRG above the melting layer. Below the melting layer, a positive gradient of $Z_{\mathrm{e}}$ was observed for almost all classes. The negative gradient of $Z_{\mathrm{e}}$ was observed only for very light rain (Figure $7 \mathrm{a})$. Very light rain also shows a clear BB pattern in the melting layer $(\sim 5 \mathrm{~km})$, which may indicate a miss classification of convective rain by the CSF module. The GPM is less sensitive to weak precipitation [45]. The gradient becomes positive when the rainfall intensity increases. The largest $Z_{\mathrm{e}}$ value was observed over land, and the smallest one was observed offshore (IOC). Although the largest $Z_{\mathrm{e}}$ value was observed over land, the VPRG value below the melting layer in this region is smaller (Figure 2). Thus, a larger raindrop size is found over land, but the raindrop growth is small in this region. 

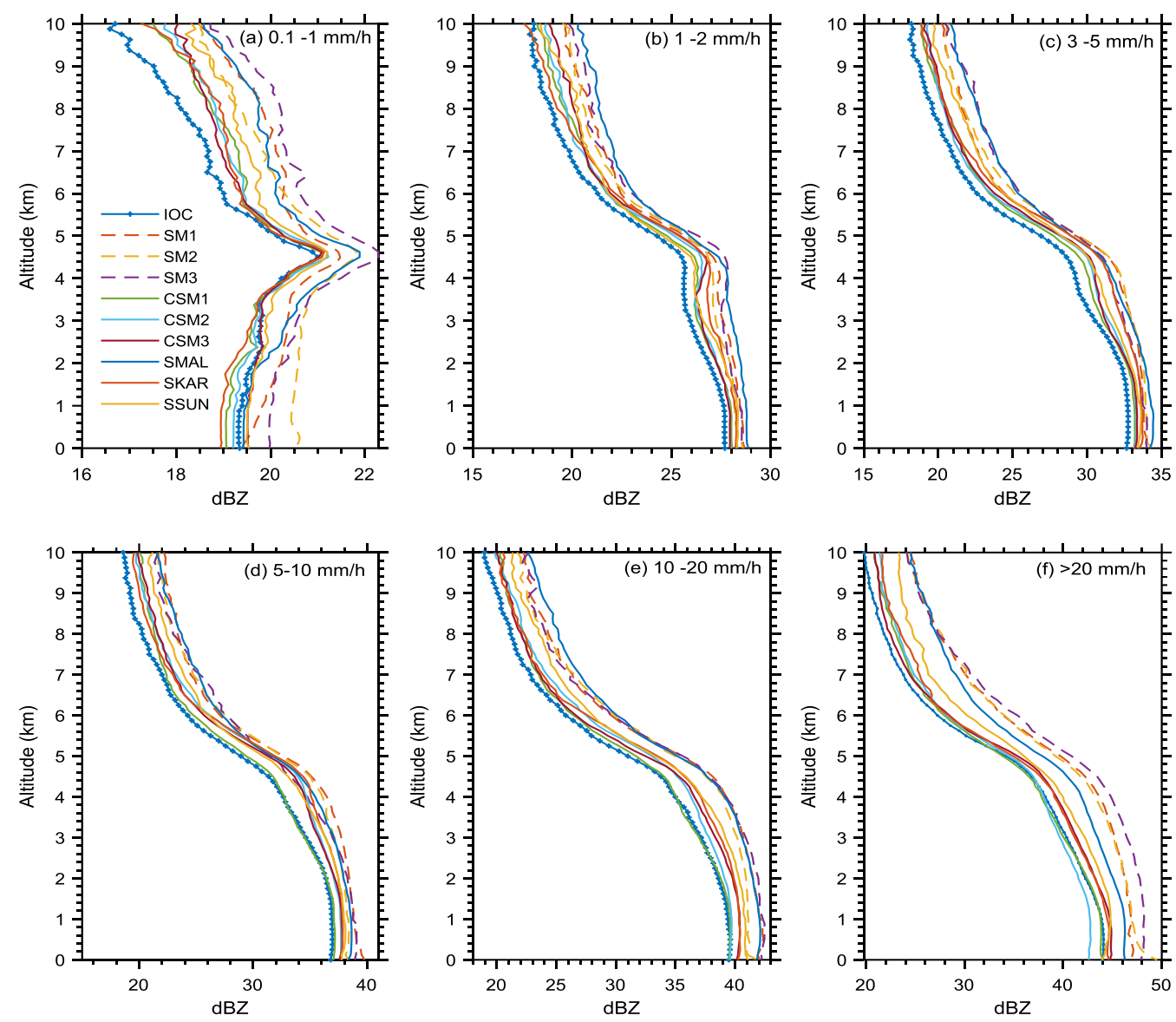

Figure 7. Vertical profile of reflectivity factor $(Z)$ for ten selected locations of convective rain for a) very light rain, b) light rain, c) moderate rain, d) heavy rain, e) very heavy rain, and f) extreme rain.
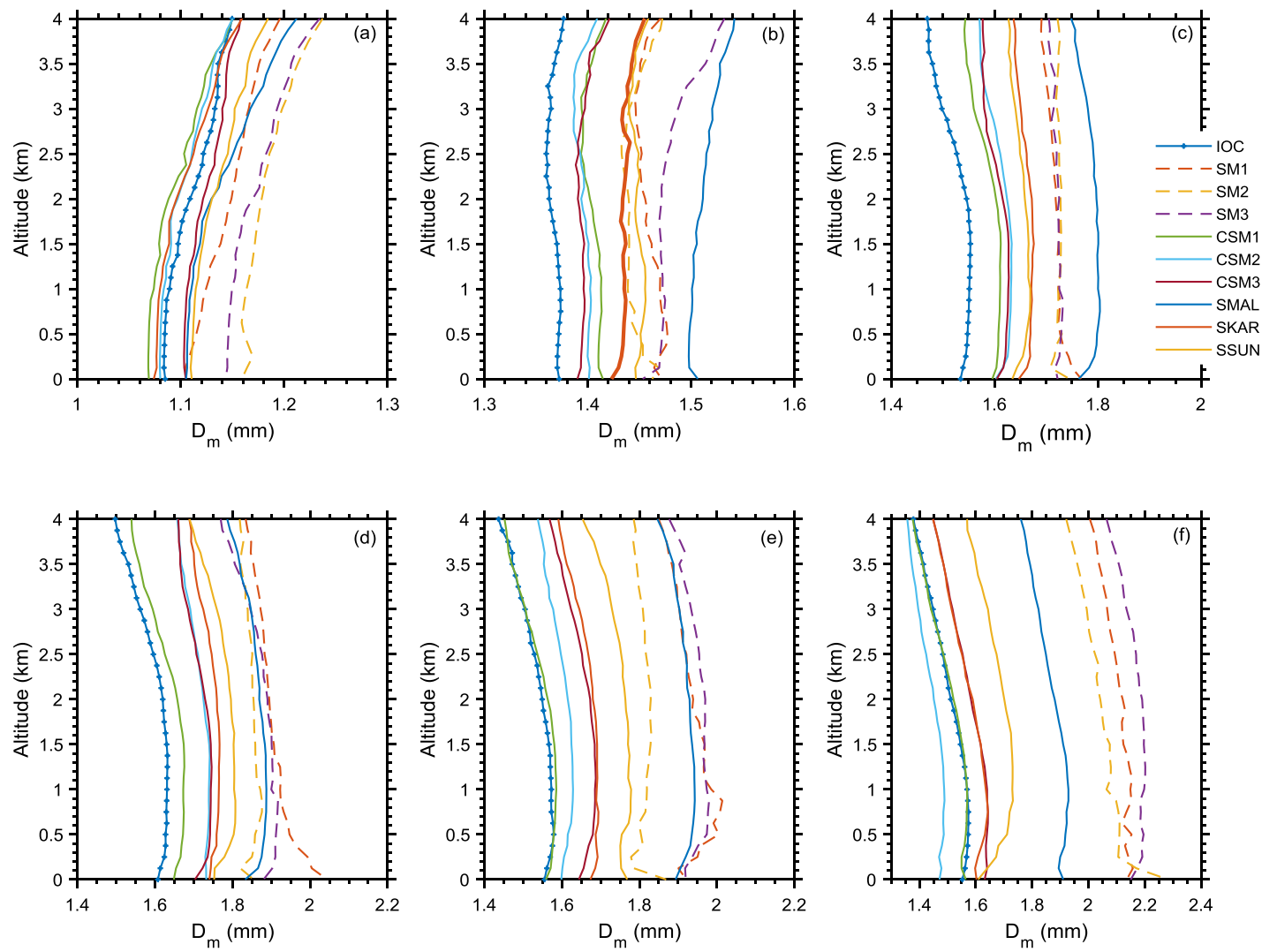

Figure 8. Vertical profile of mass-weight mean diameter $\left(D_{m}\right)$ for ten selected locations of convective rain for a) very light rain, b) light rain, c) moderate rain, d) heavy rain, e) very heavy rain, and f) extreme rain. 

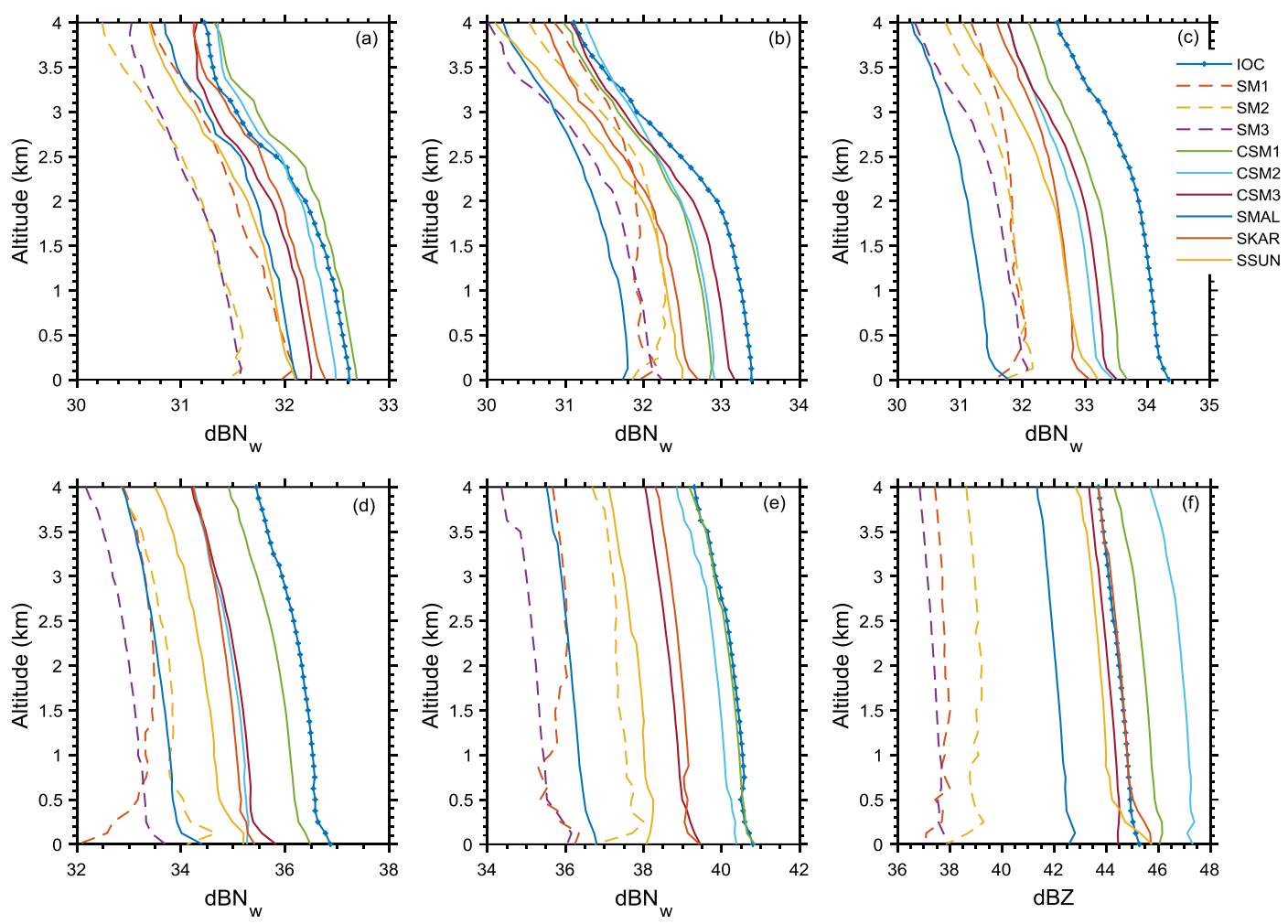

Figure 9. Vertical profile of total drop concentration $\left(\mathrm{dB} N_{\mathrm{w}}\right)$ for ten selected locations of convective rain for a) very light rain, b) light rain, c) moderate rain, d) heavy rain, e) very heavy rain, and f) extreme rain.

Figure 8 shows the vertical profile of $D_{\mathrm{m}}$ for convective rain. It can be seen that the positive gradient of $D_{\mathrm{m}}$ for higher rain intensity is larger than others, consistent with the vertical profile of $Z_{\mathrm{e}}$ (Figure 7). Furthermore, the larger positive gradient of $N_{\mathrm{w}}$ was observed for the lower intensity of convective rain for all locations (Figure 9). This pattern contrasts with the pattern of $N_{\mathrm{w}}$ for stratiform rain in which a larger positive gradient is observed for higher rain intensity. A smaller $D_{\mathrm{m}}$ gradient in lower intensity (very light to light rain) is associated with a larger $N_{\text {w }}$ gradient, indicating a more dominant break up process during raindrop's fall. The coalescence process becomes dominant when the rainfall intensity increases, which can be seen from the increase of the $D_{\mathrm{m}}$ gradient and the decrease of $N_{\mathrm{w}}$ gradient.

The largest $D_{\mathrm{m}}$ was observed over land, and the lowest one was observed over offshore (IOC). Such contrast is more obvious for a higher rain intensity. A larger $D_{\mathrm{m}}$ over land is associated with its smaller gradient in the rain column (Figure 3). Thus, intense convective rain, which is indicated by larger $Z_{\mathrm{e}}$ (Figure 7), having larger drops (indicated by large $D_{\mathrm{m}}$ ), is dominant over land. This is consistent with the variability of intense convective study in the tropical region $[38,46]$. A larger $D_{\mathrm{m}}$ value was also observed over the Malacca strait (SMAL area). Intense convective rain is also frequently generated in this region [47]. The vertical profile of $N_{\mathrm{w}}$ for convective rain is similar to stratiform rain. The largest $N_{\mathrm{w}}$ value is observed over offshore (IOC), and the smallest one is observed over land (Figure 8). Thus, the DSD of convective rain over land comprises more large-sized drop concentration with a small number of raindrop total, as observed during stratiform rain.

\section{4- Conclusion}

This study reinforces the regional variation and rain type dependence of the vertical profile of precipitation over Sumatra. The DSD over land comprises more large-sized raindrop concentration with a small number of raindrop total, indicated by a larger $D_{\mathrm{m}}$ and smaller $N_{\mathrm{w}}$ over land than over the ocean. The land-ocean contrast of raindrop growth is visible. For convective rain, the increase of large-sized drops over the ocean is more significant than over land, indicated by a larger positive $D_{\mathrm{m}}$ gradient toward the surface. On the other hand, the reduction rate of large size drop is more significant over the ocean than over land, indicated by a larger negative $D_{\mathrm{m}}$ gradient toward the surface. $Z_{\mathrm{e}}, D_{\mathrm{m}}$, and $N_{\mathrm{w}}$ 's vertical profile is also dependent on the rainfall intensity, especially for convective rain. A smaller $D_{\mathrm{m}}$ gradient in lower rain intensity (very light to light rain) is associated with a larger $N_{\mathrm{w}}$ gradient, indicating a more dominant break up process during the raindrop's fall. The coalescence process becomes dominant when the rainfall intensity increases, which can be seen from the increase of $D_{\mathrm{m}}$ gradient and the decrease of $N_{\mathrm{w}}$ gradient. In this study, we also found the shortcoming of rain classification of the CSF module. Some profiles classified as convective by the CSF module may be stratiform, indicated by strong BB pattern in the melting layer. The DSD over Sumatra is influenced by diurnal, intraseasonal, and seasonal variability of the atmosphere. The characteristics of the vertical profile of DSD in terms of these variabilities are being conducted and will be reported in other papers. 


\section{5- Declarations}

\section{5-1-Author Contributions}

Conceptualization, R.R. and M.; methodology, R.R. and M.; software, R.R. and M.; validation, M., H. and R.R.; formal analysis, R.R.; investigation, R.R.; resources, R.R.; data curation, M.; writing — original draft preparation, R.R.; writing - review and editing, M.; visualization, R.R.; supervision, M. and H.; project administration, M.; funding acquisition, M. All authors have read and agreed to the published version of the manuscript.

\section{5-2-Data Availability Statement}

Publicly available datasets were analyzed in this study. This data can be found here: www.gpm.nasa.gov/data.

\section{5-3- Funding}

The present study was supported by 2020 Magister Thesis Research Grants from the Ministry of Research, Technology, and Higher Education (Contract no: T/11/UN.16.17/PT.01.03/PTM-Kebencanaan/2020).

\section{5-4-Acknowledgements}

Thanks to NASA for providing open-source GPM Level-2 data.

\section{5-5- Conflicts of Interest}

The authors declare that there is no conflict of interests regarding the publication of this manuscript. In addition, the ethical issues, including plagiarism, informed consent, misconduct, data fabrication and/or falsification, double publication and/or submission, and redundancies have been completely observed by the authors.

\section{6- References}

[1] Jameson, A.R., and A.B. Kostinski. "What is a Raindrop Size Distribution." Bulletin of American Meteorological Society 82, no. 6 (2001): 1169-1177. doi:10.1175/1520-0477(2001)082\%3C1169:WIARSD\%3E2.3.CO;2.

[2] Tokay, A., and D.A. Short. "Evidence from tropical raindrop spectra of the origin of rain from statiform versus convective clouds." J. Appl. Meteor. 35, (1996): 355-371. doi:10.1175/1520-0450(1996)035<0355:EFTRSO>2.0.CO;2.

[3] Duhanyan, N., and Yelva Roustan. "Below-Cloud Scavenging by Rain of Atmospheric Gases and Particulates." Atmospheric Environment 45, no. 39 (2011): 7201-7217. doi:10.1016/j.atmosenv.2011.09.002.

[4] Ruan, Zheng, Hu Ming, Jianli Ma, Runsheng Ge, and Lingen Bian. "Analysis of the Microphysical Properties of a Stratiform Rain Event Using an L-Band Profiler Radar.” Journal of Meteorological Research 28, no. 2 (2014): 268-280. doi:10.1007/s13351014-3091-x.

[5] Jiang, H., M. Sano, and M. Sekine. "Weibull raindrop-size distribution and its application to rain attenuation." IEE ProceedingsMicrowaves, Antennas and Propagation 144, no. 3 (1997): 197-200. doi:10.1049/ip-map:19971193.

[6] Marzuki, M., T. Kozu, T. Shimomai, W. L. Randeu, H. Hashiguchi, and Y. Shibagaki. "Diurnal Variation of Rain Attenuation Obtained From Measurement of Raindrop Size Distribution in Equatorial Indonesia." IEEE Transactions on Antennas and Propagation 57, no. 4 (2009): 1191-1196. doi:10.1109/tap.2009.2015812.

[7] Das, S., A. Maitra, and Ashish K. Shukla. "Rain Attenuation Modeling In the 10-100 GHz Frequency using Drop Size Distributions For Different Climatic Zones In Tropical India.” Progress in Electromagnetics Research B 25 (2010): 211-224 doi:10.2528/pierb10072707.

[8] Coppens, D., and Z. S. Haddad. "Effects of Raindrop Size Distribution Variations on Microwave Brightness Temperature Calculation.” Journal of Geophysical Research: Atmospheres 105, no. D19 (2000): 24483-24489. doi:10.1029/2000jd900226.

[9] Uijlenhoet, R. "Raindrop Size Distributions and Radar Reflectivity-rain Rate Relationships for Radar Hydrology.” Hydrology and Earth System Sciences 5, no. 4 (2001): 615-628. doi:10.5194/hess-5-615-2001.

[10] Yuter, Sandra E., and Robert A. Houze Jr. "Measurements of raindrop size distributions over the Pacific warm pool and implications for Z-R relations." Journal of Applied Meteorology 36, no. 7 (1997): 847-867. doi:10.1175/15200450(1997)036<0847:MORSDO>2.0.CO;2.

[11] Atlas, D., and C. W. Ulbrich. "An observationally based conceptual model of warm oceanic convective rain in the tropics." Journal of Applied Meteorology 39, no. 12 (2000): 2165-2181. doi:10.1175/1520-0450(2001)040<2165:AOBCMO>2.0.CO;2.

[12] Ulbrich, C. W., and D. Atlas. "Microphysics of Raindrop Size Spectra: Tropical Continental and Maritime Storms." Journal of Applied Meteorology and Climatology 46, no. 11 (2007): 1777-1791. doi:10.1175/2007jamc1649.1. 
[13] Cha, J.W., K.H. Chang, S. S. Yum, and Y.J. Choi. "Comparison of the Bright Band Characteristics Measured by Micro Rain Radar (MRR) at a Mountain and a Coastal Site in South Korea.” Advances in Atmospheric Sciences 26, no. 2 (2009): $211-221$. doi:10.1007/s00376-009-0211-0.

[14] Marzuki, M., H. Hashiguchi, M. K. Yamamoto, S. Mori, and M. D. Yamanaka. "Regional Variability of Raindrop Size Distribution over Indonesia.” Annales Geophysicae 31, no. 11 (2013): 1941-1948. doi:10.5194/angeo-31-1941-2013.

[15] Hong, Song-You, and Ji-Woo Lee. "Assessment of the WRF Model in Reproducing a Flash-Flood Heavy Rainfall Event over Korea.” Atmospheric Research 93, no. 4 (2009): 818-831. doi:10.1016/j.atmosres.2009.03.015.

[16] Ramadhan, R., Marzuki, and Harmadi. "Vertical structure of raindrop size distribution over West Sumatera from global precipitation measurement (GPM) observation”. Journal of Physics: Conference Series. IOP Publishing, 2021. p. 012013. doi: doi:10.1088/1742-6596/1876/1/012013.

[17] Mori, S., Hamada J. I., Y. I. Tauhid, M. D. Yamanaka, N. Okamoto, F. Murata, N. Sakurai, H. Hashiguchi, and T. Sribimawati. "Diurnal land-sea rainfall peak migration over Sumatera Island, Indonesian Maritime Continent, observed by TRMM satellite and intensive rawinsonde soundings." Monthly Weather Review 132, no. 8 (2004): 2021-2039. doi:10.1175/15200493(2004)132<2021:DLRPMO>2.0.CO;2.

[18] Ramadhan, R., Marzuki, M. Vonnisa, Harmadi, H. Hashiguchi, and T. Shimomai. "Diurnal Variation in the Vertical Profile of the Raindrop Size Distribution for Stratiform Rain as Inferred from Micro Rain Radar Observations in Sumatra." Advances in Atmospheric Sciences 37, no. 8 (2020): 832-846. doi:10.1007/s00376-020-9176-9.

[19] Kozu, T., K. K. Reddy, S. Mori, M. Thurai, J. T. Ong, D. N. Rao, and T. Shimomai. "Seasonal and Diurnal Variations of Raindrop Size Distribution in Asian Monsoon Region.” Journal of the Meteorological Society of Japan. Ser. II 84A (2006): 195-209. doi:10.2151/jmsj.84a.195.

[20] Ramadhan, R., Marzuki, Mutya V., Harmadi, H. Hashiguhci, and T. Shimomai. "Seasonal Variation in the Vertical Profile of the Raindrop Size Distribution for Stratiform Rain as Inferred from Micro Rain Radar Observations at Kototabang." The 1st International Conference on Physics and Applied Physics (THE 1ST ICP\&AP) 2019: Fundamental and Innovative Research for Improving Competitive Dignified Nation and Industrial Revolution 4.0 (2020). doi:10.1063/5.0003181.

[21] Kozu, T., T. Shimomai, Z. Akramin, Marzuki, Y. Shibagaki, and H. Hashiguchi. "Intraseasonal Variation of Raindrop Size Distribution at Koto Tabang, West Sumatra, Indonesia." Geophysical Research Letters 32, no. 7 (2005): 1231-1249. doi:10.1029/2004g1022340.

[22] Hou, A. Y., R. K. Kakar, S. Neeck, A. A. Azarbarzin, C. D. Kummerow, M. Kojima, R. Oki, K. Nakamura, and T. Iguchi. "The Global Precipitation Measurement Mission.” Bulletin of the American Meteorological Society 95, no. 5 (2014): $701-722$. doi:10.1175/bams-d-13-00164.1.

[23] Marzuki, H. Hashiguchi, M. K. Yamamoto, M. Yamamoto, S. Mori, M. D. Yamanaka, R. E. Carbone, and J. D. Tuttle. "Cloud Episode Propagation over the Indonesian Maritime Continent from 10 years of Infrared Brightness Temperature Observations." Atmospheric Research 120-121 (2013): 268-286. doi:10.1016/j.atmosres.2012.09.004.

[24] Renggono, F., M. K. Yamamoto, H. Hashiguchi, S. Fukao, T. Shimomai, M. Kawashima, and M. Kudsy. "Raindrop Size Distribution Observed with the Equatorial Atmosphere Radar (EAR) During the Coupling Processes in the Equatorial Atmosphere (CPEA-I) Observation Campaign.” Radio Science 41, no. 5 (2006). doi:10.1029/2005rs003333.

[25] Marzuki, H. Hashiguchi, T. Shimomai, I. Rahayu, M. Vonnisa, and Afdal. "Performance Evaluation of Micro Rain Radar over Sumatra through Comparison with Disdrometer and Wind Profiler." Progress In Electromagnetics Research M 50 (2016): 3346. doi:10.2528/pierm16072808.

[26] Gorgucci, E., and L. Baldini. "Performance Evaluations of Rain Microphysical Retrieval Using Gpm Dual-Wavelength Radar by Way of Comparison With the Self-Consistent Numerical Method." IEEE Transactions on Geoscience and Remote Sensing 56, no. 10 (2018): 5705-5716. doi:10.1109/tgrs.2018.2824399.

[27] Chandrasekar, V., S. K. Biswas, M. Le, and H. Chen. "Cross Validation of Raindrop Size Distribution Retrievals from GPM Dual-Frequency Precipitation Radar Using Ground-Based Polarimetric Radar.” IGARSS 2018- IEEE International Geoscience and Remote Sensing Symposium (2018): 8335-8338. doi:10.1109/igarss.2018.8518881.

[28] Petracca, M., L. P. D’Adderio, F. Porcù, G. Vulpiani, S. Sebastianelli, and S. Puca. "Validation of GPM Dual-Frequency Precipitation Radar (DPR) Rainfall Products over Italy.” Journal of Hydrometeorology 19, no. 5 (2018): 907-925. doi:10.1175/jhm-d-17-0144.1.

[29] Kubota, T., N. Yoshida, S. Urita, T. Iguchi, S. Seto, R. Meneghini, J. Awaka, H. Hanado, S. Kida, and R. Oki. "Evaluation of Precipitation Estimates by at-Launch Codes of GPM/DPR Algorithms Using Synthetic Data from TRMM/PR Observations." IEEE Journal of Selected Topics in Applied Earth Observations and Remote Sensing 7, no. 9 (2014): 3931-3944. doi:10.1109/jstars.2014.2320960.

[30] Hamada, A., and Y. N. Takayabu. "Improvements in Detection of Light Precipitation with the Global Precipitation Measurement Dual-Frequency Precipitation Radar (GPM DPR).” Journal of Atmospheric and Oceanic Technology 33, no. 4 (2016): $653-667$. doi:10.1175/jtech-d-15-0097.1. 
[31] Awaka, J., M. Le, V. Chandrasekar, N. Yoshida, T. Higashiuwatoko, T. Kubota, and T. Iguchi. "Rain Type Classification Algorithm Module for GPM Dual-Frequency Precipitation Radar.” Journal of Atmospheric and Oceanic Technology 33, no. 9 (2016): 1887-1898. doi:10.1175/jtech-d-16-0016.1.

[32] Seto, S., and T. Iguchi. "Applicability of the Iterative Backward Retrieval Method for the GPM Dual-Frequency Precipitation Radar.” IEEE Transactions on Geoscience and Remote Sensing 49, no. 6 (2011): 1827-1838. doi:10.1109/tgrs.2010.2102766.

[33] Watters, D., A. Battaglia, K. Mroz, and F. Tridon. "Validation of the GPM Version-5 Surface Rainfall Products over Great Britain and Ireland.” Journal of Hydrometeorology 19, no. 10 (2018): 1617-1636. doi:10.1175/jhm-d-18-0051.1.

[34] Seto, S., T. Iguchi, and T. Oki. "The basic performance of a precipitation retrieval algorithm for the global precipitation measurement mission's single/dual-frequency radar measurements." IEEE Transactions on Geoscience and Remote Sensing 51, no. 12 (2013): 5239-5251. doi:10.1109/TGRS.2012.2231686.

[35] Tokay, A., L. P. D’Adderio, F. Porcù, D. B. Wolff, and W. A. Petersen. “A Field Study of Footprint-Scale Variability of Raindrop Size Distribution.” Journal of Hydrometeorology 18, no. 12 (2017): 3165-3179. doi:10.1175/jhm-d-17-0003.1.

[36] Le, M., and V. Chandrasekar. "An Algorithm for Drop-Size Distribution Retrieval from GPM Dual-Frequency Precipitation Radar.” IEEE Transactions on Geoscience and Remote Sensing 52, no. 11 (2014): 7170-7185. doi:10.1109/tgrs.2014.2308475.

[37] Huffman, G. J., D. T. Bolvin, D. Braithwaite, K. Hsu, R. Joyce, P. Xie, and S. H. Yoo. "NASA global precipitation measurement (GPM) integrated multi-satellite retrievals for GPM (IMERG)." Algorithm Theoretical Basis Document (ATBD) Version 4 (2015): 26.

[38] Yusnaini, H., and. Marzuki. "Vertical Distribution of Radar Reflectivity Factor in Intense Convective Clouds over Indonesia." KnE Engineering 1, no. 2 (2019): 141-147. doi:10.18502/keg.v1i2.4439.

[39] Marzuki, H. Hashiguchi, M. Vonnisa, and Harmadi. "Seasonal and Diurnal Variations of Vertical Profile of Precipitation over Indonesian Maritime Continent." Engineering and Mathematical Topics in Rainfall (April 18, 2018 ): 71. doi:10.5772/intechopen.74044.

[40] Rulfová, Zuzana, and Jan Kyselý. "Disaggregating Convective and Stratiform Precipitation from Station Weather Data." Atmospheric Research 134 (2013): 100-115. doi:10.1016/j.atmosres.2013.07.015.

[41] Rosenfeld, D., and C. W. Ulbrich. "Cloud Microphysical Properties, Processes, and Rainfall Estimation Opportunities.” Radar and Atmospheric Science: A Collection of Essays in Honor of David Atlas. American Meteorolgy Society. (2003): $237-258$. doi:10.1007/978-1-878220-36-3_10.

[42] Marzuki, H. Hashiguchi, T. Shimomai, I. Rahayu, M. Vonnisa, and Afdal. "Performance Evaluation of Micro Rain Radar over Sumatra through Comparison with Disdrometer and Wind Profiler." Progress In Electromagnetics Research M 50 (2016): $33-$ 46. doi:10.2528/pierm16072808.

[43] Wang, H., H. Lei, and J. Yang. "Microphysical Processes of a Stratiform Precipitation Event over Eastern China: Analysis Using Micro Rain Radar Data.” Advances in Atmospheric Sciences 34, no. 12 (2017): 1472-1482. doi:10.1007/s00376-017-7005-6.

[44] Bringi, V. N., V. Chandrasekar, J. Hubbert, E. Gorgucci, W. L. Randeu, and M. Schoenhuber. "Raindrop size distribution in different climatic regimes from disdrometer and dual-polarized radar analysis." Journal of the atmospheric sciences 60, no. 2 (2003): 354-365. doi:10.1175/1520-0469(2003)060<0354:RSDIDC >2.0.CO;2.

[45] Zhang, Aoqi, and Yunfei Fu. "The structural characteristics of precipitation cases detected by dual-frequency radar of GPM satellite." Chin. J. Atmos. Sci 42 (2018): 33-51.

[46] Kumar, S., and G. S. Bhat. "Vertical Profiles of Radar Reflectivity Factor in Intense Convective Clouds in the Tropics." Journal of Applied Meteorology and Climatology 55, no. 5 (2016): 1277-1286. doi:10.1175/jamc-d-15-0110.1.

[47] Chen, H., P. M. Rizzoli, T.Y. Koh, and G. Song. "The Relative Importance of the Wind-Driven and Tidal Circulations in Malacca Strait.” Continental Shelf Research 88 (2014): 92-102. doi:10.1016/j.csr.2014.07.012. 